\title{
A comprehensive ethno-pharmacological review on Lippia alba M
}

\author{
Mamun-Or-Rashid A. N. M. ${ }^{1}$, Sen M. K. ${ }^{1,}$, Jamal M. A. H. M. ${ }^{1}$, Nasrin. $\mathrm{S}^{2}$ \\ ${ }^{1}$ Department of Biotechnology and Genetic Engineering, Faculty of Applied Science and Technology, Islamic University, Kushtia-7003, \\ Bangladesh \\ ${ }^{2}$ Scientific Officer, Plant Biotechnology Division, National Institute of Biotechnology, Savar, Dhaka, Bangladesh
}

\section{Email address:}

Monokeshsen@yahoo.com(Sen M. K.)

\section{To cite this article:}

Mamun-Or-Rashid A. N. M., Sen M. K., Jamal M. A. H. M., Nasrin S. A Comprehensive Ethnopharmacological Review on Lippia Alba M. International Journal of Biomedical Materials Research. Vol. 1, No. 1, 2013, pp. 14-20. doi: 10.11648/j.ijbmr.20130101.13

\begin{abstract}
The present comprehensive review was conducted in the Department of Biotechnology and Genetic Engineering of Islamic University, Kushtia, to pile up update ethno-pharmacological information of Lippia alba (Mill) that is available in different scientific literatures. L. alba, belongs to the family of verbenaceae, found everywhere in Bangladesh and it is commonly used in folk medicine to treat gastric illnesses, diarrhea, fever, asthma, malaria, and inflammation. Phytochemical analysis showed that the crude extract of fresh leaves consists of some valuable essential oils and that is found to be effective against bacteria, fungus, protozoa, and virus. The present paper also covers the taxonomy, morphology, monograph, usable parts, and distribution of this valuable medicinal plant.
\end{abstract}

Keywords: Lippia Alba, Ethno-Pharmacological, Folk Medicine, Phytochemical Analysis

\section{Introduction}

Long before mankind discovered the existence of microbes, the idea that certain plants had healing potential, indeed, that they contained what we would currently characterize as antimicrobial principles, was well accepted. Since antiquity, man has used plants to treat common infectious diseases and some of these traditional medicine are still included as part of the habitual treatment of various maladies [1-3]. Over the past 20 years, there has been an increased interest in the investigation of natural materials as sources of new antibacterial agents. In the recent years, the development of resistance of pathogens against antibiotics has become a difficult issue caused by the indiscriminate use of modern antibiotics [4]. Considering the high cost of the synthetic drugs and their side effects, wide varieties of natural plants can be considered as a vital source for anti-microbial agents [4]. Therefore, the demand for new and effective anti-microbial agents with broad-spectrum of activity from natural sources is increasing day by day [4].

Lippia alba (Mill.) N.E. Brown, also known as Lippia geminata HBK or Lantana alba (Mill), was one of the first two plants from overseas departments to be approved by the French Drug Agency (AFSSaPS) for inclusion in the French Pharmacopeia [5] is a shrub about $3 \mathrm{~m}$ tall that belongs to the
Verbenaceae family [6, 3] and it is abundantly present between the south of the USA, the north of Argentina, Bangladesh [4] and also present in India [7] and Australia [8]. In the traditional medicine of Brazil the species L. alba is used as a remedy for stomach disorders [9-11], antibacterial and antiseptic for infectious diseases influenza, measles, rashes, and headaches [11-12]. The plant presents a great morphological and chemical variability that Matos suggested the division into different chemotypes [13, 11]. So far, at least 12 chemotypes have been described: citral $[13,11]$, linalool $[14,11]$, carvone $[13,11]$, limonene $[15$, $11], \gamma$-terpinene $[16,11]$, citral-myrcene $[14,11]$, citral-limonene $[14,11]$, citral- $\beta$-caryophyllene $[17,11]$, citral-germacrene-D [18, 11], carvonelimonene [14, 11], 1,8-cineol-camphor [19, 11], 1,8-cineollimonene [18, 11], limonene-piperitone [20, 11]. GC analyses of essential oils from $L$. alba revealed the predominance of monoterpene type compounds such as citral, $\beta$-myrcene, limonene and carvone $[20,11]$.

The purpose of this review was the documentation and to compare the chemical composition, pharmacological aspects and traditional uses which have been identified in the literature concerning to L. alba species, in order to uncovering records of other compounds, new flavoring substances and their relationships. 


\subsection{Taxonomy of L. alba}

Medicinal plants are classified according to the part used, habit, habitat, therapeutic value etc., besides the usual botanical classification. But the botanical classification is the most comprehensive and scientific classification. The botanical classification of L. alba is as following:

$\begin{array}{ll}\text { Kingdom } & \text { Plantae-Plants } \\ \text { Division } & \text { Magnoliophyta-Flowering plants } \\ \text { Class } & \text { Magnoliopsida-Dicotyledons } \\ \text { Order } & \text { Lamiales } \\ \text { Family } & \text { Verbenaceae-Verbena family } \\ \text { Genus } & \text { Lippia } \\ \text { Species } & \text { Lippia alba (Mill.) }[21]\end{array}$

\subsection{Synonyms}

Its common names include Bushy Matgrass [21], Bushy Lippia, and Hierba Negra. Bangali name is Motmote.

\subsection{Plant Parts Used}

Bushy Lippia is widely cultivated as an ornamental for its aromatic foliage and beautiful flowers [22]. The leaves have many medicinal uses and are also used for flavoring foods [23]. Leaves are used as an infusion against states of excitement, hypertension, digestive troubles, nausea and cold, to heal wounds locally and as syrup against cough and bronchitis. An infusion of the roots is also used against bad colds and coughs [24, 4]. Besides, the leaves from the majority of these species are utilized as seasoning for food preparations $[25,12]$.

\subsection{Monograph}

Bengali name

English name

Scientific name

Family

Duration

Growth habit

Bang: nativity

\subsection{Morphology}

It is a shrub, with a quadrangular branch, reaching $1.7 \mathrm{~m}$ in height. The leaves are membranaceous, petiolate, pubescent, opposite or ternate, and its limb shows variable forms with a pointed apex, cuneiform or decumbent basis and serrated or crenated border (except on the basis). The flowers $(3-5 \mathrm{~mm})$ are white or pink. The fruit is composed of two indehiscent nucleous, each containing one brown seed [26-28].

\subsection{Distribution}

L. alba is an aromatic perennial shrub with huge medicinal properties distributed throughout the world. It grows well in Bangladesh, India, Mexico, Paraguay, Brazil, Uruguay, the south of the USA, the north of Argentina and Australia [7, 8, 4].

\section{Phytochemistry}

The plant contains borneol, camphor $\beta$-cubebene, $\beta$-elemene, $\gamma$-cadinene, allo-aromadendrene and so on. Root powder of plant contains terpenoids, phenylpropanoids and sugar. The chemical constituents of L. alba are shown in Table 1.

Table 1 Chemical constituents of L. alba

\begin{tabular}{|c|c|c|}
\hline Parts used & Constituents & References \\
\hline Root powder & Terpenoids, phenylpropanoids, and sugars & {$[3]$} \\
\hline Leaves & $\begin{array}{l}\text { Borneol, camphor, } 1,8 \text {-cineole, citronellol, geranial, linalool, myrcene, } \\
\text { neral, piperitone, sabinene, } 2 \text {-undecanone, } \alpha \text {-muurolene, } \\
\beta \text {-caryophyllene, } \beta \text {-cubebene, } \beta \text {-elemene, } \gamma \text {-cadinene, } \\
\text { allo-aromadendrene, caryophyllene oxide. }\end{array}$ & {$[17,25,29,12]$} \\
\hline
\end{tabular}

\section{Folk Remedies and Traditional Uses}

Leaves are used as an infusion against states of excitement, hypertension, digestive troubles, nausea and cold, to heal wounds locally and as syrup against cough and bronchitis. An infusion of the roots is also used against bad colds and coughs [24]. It is also used as a sedative and also against hypertension, flatulence and pain [30]. In Itacare, it is used against stomach ache and digestive troubles with high concordance between informants [31]. In a Mixe community, in Mexico, the leaves of $L$. alba were frequently cited by traditional healers as active against gastrointestinal troubles [9]. Various traditional uses of the L. alba are mentioned in Table 2. 
Table 2 Folk remedies and traditional uses of L. alba

\begin{tabular}{|c|c|c|c|}
\hline Type of use & Symptoms & Part used and method & References \\
\hline \multirow{6}{*}{ Digestive } & Digestive troubles in general & Leaves, infusion & [24] \\
\hline & Nausea and/or vomiting & Leaves, infusion & [24] \\
\hline & & Leaves, smoking & [32] \\
\hline & Stomach pain & Leaves & [9] \\
\hline & Flatulence & Leaves, infusion & [32] \\
\hline & Diarrhea & n.k. & [33] \\
\hline \multirow{8}{*}{ Respiratory } & Respiratory ailments in general & Leaves infusion or decoction & [34] \\
\hline & Bronchitis & Leaves, syrup & [24] \\
\hline & Sore throat & Leaves, infusion & [35] \\
\hline & Flu & Leaves, infusion & [35] \\
\hline & & Leaves, decoction & [32] \\
\hline & Cough & Leaves, syrup & [24] \\
\hline & & Roots, infusion & [33] \\
\hline & Cold & Leaves, infusion & [24] \\
\hline \multirow{3}{*}{ Sedative } & & Leaves, infusion & [24] \\
\hline & & Leaves and flowers, infusion or decoction & [34] \\
\hline & & Leaves & [36] \\
\hline \multirow{2}{*}{ Cardiovascular } & & Leaves, infusion & [24] \\
\hline & Hypertension & Leaves, infusion or decoction & [34] \\
\hline \multirow{5}{*}{ Miscellaneous } & Anemia & Leaves & [37] \\
\hline & Headache & Leaves, poultice & [32] \\
\hline & Pain & n.k. & [30] \\
\hline & Skin diseases & Leaves, macerate for washing & {$[32]$} \\
\hline & Wounds & Leaves, local use & [24] \\
\hline
\end{tabular}

\section{Pharmacology}

Following the folk and traditional uses of the plant, it has been investigated scientifically to validate the potential of the plant in cure of variety of ailments. Some of the reported pharmacological activities of $L$. alba are mentioned in Table 3.

Table 3 Pharmacological activities of L. alba

\begin{tabular}{|c|c|c|c|c|}
\hline \multicolumn{4}{|c|}{ Pharmacological Activity } & \multirow{2}{*}{$\begin{array}{l}\text { References } \\
{[38,39,40,34,4]}\end{array}$} \\
\hline \multirow{4}{*}{$\begin{array}{l}\text { Ati-infectious } \\
\text { properties }\end{array}$} & \multirow{4}{*}{$\begin{array}{l}\text { Antibacterial } \\
\text { activities }\end{array}$} & $\begin{array}{l}\text { Bacilli } \\
\text { Gram }+\end{array}$ & B. subtilis, L. casei, S. lutea & \\
\hline & & $\begin{array}{l}\text { Cocci } \\
\text { Gram }+\end{array}$ & $\begin{array}{l}\text { E. faecalis, M. luteus, S. aureus, S. aureus, S. } \\
\text { epidermidis, S.mutans }\end{array}$ & {$[38,39,41,40,34]$} \\
\hline & & $\begin{array}{l}\text { Bacilli } \\
\text { Gram - }\end{array}$ & $\begin{array}{l}\text { E. aerogenes, E. coli, } K \text {. pneumonia, } P \text {. } \\
\text { aeruginosa, Salmonella sp., S. marcescens, } S . \\
\text { flexneri, } S . \text { sonnei, X. campestris }\end{array}$ & {$[38,42,39,43,41,40,4]$} \\
\hline & & $\begin{array}{l}\text { Mycobact } \\
\text { eria }\end{array}$ & M. smegmatis, M. smegmatis & {$[42,40]$} \\
\hline
\end{tabular}




\begin{tabular}{|c|c|c|c|}
\hline \multirow{5}{*}{$\begin{array}{l}\text { Effect on the } \\
\text { nervous system }\end{array}$} & $\begin{array}{l}\text { Antifungal } \\
\text { activities }\end{array}$ & $\begin{array}{l}\text { C. albicans, C. albicans serotype B, C. guilliermondii, } C \text {. } \\
\text { krusei, } C \text {. parapsilosis, } C \text {. tropicalis, } C \text {. sitophila, } C \text {. } \\
\text { neoformans } \mathrm{T} 1-444 \text { Serotype A, F. pedrosoi 5VPL, } T \text {. } \\
\text { rubrum } \mathrm{T} 544\end{array}$ & {$[39,44,34,40]$} \\
\hline & Antiviral activity & HSV-1, influenza virus type A (H3N2), poliovirus type 2 & {$[45,46,47]$} \\
\hline & $\begin{array}{l}\text { Antiprotozoal } \\
\text { activity }\end{array}$ & $\begin{array}{l}\text { E. histolytica, G. lamblia, T. vaginalis, P. falciparum D-6 } \\
\text { clone }\end{array}$ & {$[48,49,42]$} \\
\hline & \multicolumn{2}{|c|}{ Neurosedative activity } & {$[50,51,52,53,54]$} \\
\hline & \multicolumn{2}{|c|}{ Analgesic and anti-inflammatory activities } & {$[55,40]$} \\
\hline \multirow[t]{2}{*}{$\begin{array}{l}\text { Cardiovascular } \\
\text { activity }\end{array}$} & & & {$[56,57]$} \\
\hline & \multicolumn{2}{|l|}{ Antioxidant activity } & {$[58,59,54]$} \\
\hline & \multicolumn{2}{|l|}{ Cytotoxic activity } & {$[60,40]$} \\
\hline
\end{tabular}

\section{Toxicological Study}

Aguiar, 2006 determined the oral LD50 of L. alba extracts, the values being $460 \mathrm{mg} / \mathrm{kg}$ for an ethanolic leaf extract and $1466 \mathrm{mg} / \mathrm{kg}$ for a chloroformic root extract in mice [40].

\section{Discussion}

Antibiotics provide the main basis for the therapy of bacterial infections. However, the high genetic variability of bacteria enables them to rapidly evade the action of antibiotics by developing antibiotic resistance. Thus there has been a continuing search for new and more potent antibiotics. According to World Health Report on infectious diseases 2000, overcoming antibiotic resistance is the major issue of the WHO for the next millennium. Hence, the last decade witnessed an increase in the investigations on plants and spices as a sources of human management [61] and more natural antimicrobials has driven scientist to investigate the effectiveness of inhibitory compounds such as extract from plants [62].

Numerous papers have presented ethno-pharmacological studies dealing with $L$. alba. Its leaves are employed as infusion or decoction to the treatment of various digestive problems, gastric illnesses, diarrhea, fever, asthma, cough, cardiovascular and tranquillizing remedy [13, 3]. Large variations have been observed in the composition of $L$. alba essential oil, depending on the part of the plant employed in the distillation, on the plant's state of development and on the geographic location, the characteristics of the soil, climate, and others local conditions $[6,3]$. GC analyses of essential oil from three chemotypes of $L$. alba revealed the predominance of monoterpene type compounds such as citral $(55.1 \%), \beta$-myrcene $(10.5 \%)$, and limonene $(1.5 \%)$ $[13,3]$. The essential oil of $L$. alba showed antimicrobial activity against gram positive microorganisms, in general, with minimum inhibitory concentration (MIC) between $0.31-0.63 \mathrm{mg} / \mathrm{mL}$ [3]. Its extract is active against a large number of both gram positive and gram negative bacteria, fungus, even it is active against several disease causing virus and protozoa (Table 3). It has neurosedative activity, analgesic and anti-inflammatory activities, antioxidant activity, cytotoxic activity (Table 3 ) too. That means it can be used in a broad range of human health care purpose by identifying the chemicals that posses the medicinal activity and can be used as a potent drug to treat these types of human disease instead of antibiotics which showed much side effects to people.

\section{Conclusion}

L. alba is a world-wide popular medicinal plant that is considered useful in numerous ailments, mainly digestive, respiratory, sedative, cardiovascular troubles and anxiety. Antitumor potential is the exciting aspects of the plant. The plant is a potent gastro protective too. Several investigators have reported the plant as a valuable antibacterial, antifungal and active against other plant pathogens. Presence of wide range of phytochemicals and pharmacological activity indicates its promise in herbal medicine for multidisciplinary usages. The pharmacological experiments performed in the plant must be extended to the next level of clinical trial to generate novel drugs. This might prove helpful to use its immense therapeutic efficacy as a potent phytomedicine.

\section{Conflict of Interest Statement}

The authors declare that they have no conflict of interest. 


\section{Acknowledgement}

The corresponding author wish to thank the Department of Biotechnology and Genetic Engineering, Islamic University, Kushtia.

\section{References}

[1] Heinrich M, Barnes J, Gibbons S and Williamson EM. Fundamental of Pharmacognosy and Phytotherapy. Churchill Livingstone, Edinbrugh. 2004.

[2] Rios JL and Recio MC. Medicinal plants and antimicrobial activity. J. Ethnopharmacol. 2005; 100: 80-84.

[3] Jose GSF, Janaina GSM, Antonio MS, Ademario MG, Maria NCP and Haroudo SX. Antimicrobial activity and phytochemical profi le from the roots of Lippia alba (Mill.) N.E. Brown. Brazilian J. Pharmacog. 2006; 16(4): 506-509.

[4] Mamun-or-Rashid ANM, Islam MR and Dash BK. In vitro Antibacterial Effect of Bushy Matgrass (Lippia alba Mill.) Extracts. Res. J. Med. Plant. 2012; 6: 334-340.

[5] Robard I. Plantes medicinales doutre-mer et pharmacopees: aspects juridiques, economiques et culturels. Phytotherapie-De la Recherche a la Pratique. 2003; 1: 16-21.

[6] Stashenko EE, Jaramillo BE andMartinez JR. Comparison of different extraction methods for the analysis of volatile secondary metabolites of Lippia alba (Mill.) N.E. Brown, grown in Colombia, and evaluation of its in vitro antioxidant activity. J. Chromatography A. 2003; 1025: 93-103.

[7] Singh G, Rao GP, Kapoor PS and Singh OP. Chemical constituents and antifungal activity of Lippia alba Mill. leaf essential oil. J. Med. Aro. Plant Sci. 2000; 22: 701-703.

[8] Day MD and Mc Andrew TD. The biology and host range of Falconia intermedia (Hemiptera: Miridae), a potential biological control agent for Lantana camara (Verbenaceae) in Australia. Biocon. Sci.Technol. 2003; 13: 13-22.

[9] Heinrich $\mathrm{M}$, Rimpler $\mathrm{H}$ and Barrera NA. Indigenous phytotherapy of gastrointestinal disorders in a lowland Mixe community (Oaxaca, Mexico) ethnopharmacologic evaluation. J. Ethnopharmacol. 1992; 36: 63-80.

[10] Caceres AL, Fletes L, Aguilar O, Ramires L, Figueroa AM, Taracena BE and Samayoa. Plants used in Guatemala for the treatment of gastrointestinal disorders. 3. Confirmation of activity against enterobacteria of 16 plants. J. Ethnopharmacol. 1993; 38: 31-38.

[11] Marisa AN, Gaspar D, Luciana S and Patricia MT. Antibacterial Activity of Lippia alba (Lemon Herb). Latin America J. Pharmacol. 2007; 26(3): 404-406.

[12] Pascual M, Slowing EK, Carretero E, Sanchez Mata D, Villar A. J. Ethnopharmacol. 2001; 76: 201-214.
[13] Matos FJA. As ervas cidreiras do nordeste do Brasil. Estudo de três quimiotipos de Lippia alba (Mill). N.E.BrVerbenaceae. Revista Brasileira de Ciências Farmacêuticas 1996; 77: 137-141.

[14] Frighetto N, Oliveira JG, Siani AC and Chagas KC. J. Essential Oil Res. 1998; 10: 578-580.

[15] Pino A, Luiz AGO, Peres AR, Jorge MR and Baluja R. Revista Cubana de Farmacia. 1997; 30:29-35.

[16] Gomes EC, Ming LC, Moreira EA, Miguel OG, Miguel MD, Kerber VA, Conti A and Filho AW. Revista Brasileira de Ciências Farmacêuticas. 1993; 74: 29-32.

[17] Craveiro AA, Alencar JW, Matos FJA, Andrade CHS, Machado MIL. Essential oils from Brazilian Verbenaceae genus Lippia. J.Nat. Pro.1981; 44: 598-601.

[18] Zoghbi MGB, Andrade EHA, Santos AS, Silva MHL and Maia JGS. Flavour Fragrance J. 1988; 14: 411-414.

[19] Dellacassa E, Soler E, Menéndez P and Moyna P. Revista Brasileira de Ciências Farmacêuticas. 1990; 5: 107-108.

[20] Senatore F and Rigano D. Essential oil of two Lippia spp. (Verbenaceae) growing wild in Guatemala. Flavour and Fragrance J. 2001; 16: 169-171.

[21] Britton NL and Wilson P. Botany of Porto Rico and the Virgin Islands. Scientific Survey of Porto Rico and the Virgin Islands. New York Academy of Sciences, New York. 1926.

[22] Tucker AO and Thomas DB. The Encyclopedia of Herbs: A Comprehensive Reference to Herbs of Flavor and Fragrance (2 ed.). Timber Press. 2009.

[23] Duke JA. Duke's Handbook of Medicinal Plants of Latin America. CRC Press. 2008: 412-414.

[24] Di Stasi LC, Oliveira GP, Carvalhaes MA, Queiroz-Junior M, Tien OS, Kakinami SH and Reis MS. Medicinal plants popularly used in the Brazilian Tropical Atlantic Forest. Fitoterapia. 2002; 73: 69-91.

[25] Morton. Atlas of Medicinal Plants of Middle America, vol. I. Springfield, Illinois, USA. 1981: 745-750.

[26] Adams CD. Flowering Plants of Jamaica. University of the West Indies, Glasgow University Press, Glasgow. 1972.

[27] Fournet J. Flore Illustree des Phanerogames de Guadeloupe et de Martinique (tome 2). CIRAD, Gondwana Editions, Tartane. 2002.

[28] Howard RA. Flora of the Lesser Antilles. Arnold Arboretum, Harvard University, Jamaica Plain, Massachussetts. 1989.

[29] Terblanche FC, Kornelius G. Essential oil constituents of the genus Lippia (Verbenaceae)-A literature review. J. Essential Oil Res. 1996; 8: 471-485.

[30] Rodrigues ACC and Guedes MLS. Utilizac, ao de plantas 
medicinais no Povoado Sapucaia, Cruz das Almas-Bahia. Revista Brasileira de Plantas Medicinais. 2006; 8: 1-7.

[31] Pinto EPP, Amorozo MCM, Furlan A. Conhecimento popular sobre plantas medicinais em comunidades rurais de mata atlantica-Itacar'e, BA, Brasil. Acta Botanica Brasilica. 2006; 20: 751-762.

[32] Giron LM, Freire V, Alonz A and Caceres A. Ethnobotanical survey of the medicinal flora used by the Caribs of Guatemala. J. Ethnopharmacol. 1991; 34: 173-187.

[33] Toscano-Gonzalez JY. Uso tradicional de plantas medicinales en la vereda San Isidro, municipio de San Jose de Pare-Boyaca: un estudio preliminary usando tecnicas cuantitativas. Acta Biologica Colombiana. 2006; 11: 137-146.

[34] Oliveira DR, Leitao GG, Santos SS, Bizzo HR, Lopes D, Alviano CS, Alviano DS and Leitao SG. Ethnopharmacological study of two Lippia species from Oriximina, Brazil. J. Ethnopharmacol. 2006; 108: 103-108.

[35] Franco EAP, Barros RFM. Uso e diversidade de plantas medicinais no Quilombo Olho Dagua dos Pires, Esperantina Piau. Revista Brasileira de Plantas Medicinais. 2006; 8: $68-88$

[36] Vendruscolo GS, Mentz LA. Estudo da concordancia das citac, oes de uso e importancia das especies e famılias utilizadas como medicinais pela comunidade do bairro Ponta Grossa, Porto Alegre, RS, Brasil. Acta Botanica Brasilica. 2006; 20: 367-382.

[37] Gazzaneo LRS, de Lucena RFP, de Albuquerque UP. Knowledge and use of medicinal plants by local specialists in a region of Atlantic Forest in the state of Pernambuco (Northeastern Brazil). J. Ethnobiol. Ethnomed. 2005 1: 1-8.

[38] Pino Alea JA, Ortega Luis AG, Rosado Perez A, Rodriguez Jorge $\mathrm{M}$ and Baluja $\mathrm{R}$. Composicion y propiedades antibacterianas del aceite esencial de Lippia alba (Mill.) N.E. Brown. Revista Cubana de Farmacia. 1996: 30: 1-10.

[39] Holetz FB, Pessini GL, Sanches NR, Cortez DAG, Nakamura CV and Filho BPD. Screening of some plants used in the brazilian folk medicine for the treatment of infectious diseases. Memorias do Instituto Oswaldo Cruz. 2002; 97 : 1027-1031.

[40] Aguiar JS. Atividades antimicrobiana, citotoxica, antitumoral e antiinflamatoria de extratos brutos de Lippia alba (Mill.) N.E. Brown. Mestrado em ciencias biologicas, Universidade de Pernambuco. 2006.

[41] Sena Filho JG, Melo JGS, Saraiva AM, Gonc,alves AM, Psiottano MNC and Xavier HS. Antimicrobial activity and phytochemical profile from the roots of Lippia alba (Mill.) N.E. Brown. Revista Brasileira de Farmacognosia. 2006; 16: 506-509.
[42] Antoun MD, Ramos Z, Vazques J, Oquendo I, Proctor GR, Gerena L and Franzblau SG. Evaluation of the flora of Puerto Rico for in vitro antiplasmodial and antimycobacterial activities. Phytother. Res. 2001; 15: 638-642.

[43] Alanis AD, Calzada F, Cervantes JA, Torres J, Ceballos GM. Antibacterial properties of some plants used in Mexican traditional medicine for the treatment of gastrointestinal disorders. J. Ethnopharmacol. 2005; 100: 153-157.

[44] Duarte MCT, Figueira GM, Sartoratto A, Rehder VLG and Delarmelina C. Anti-Candida activity of Brazilian medicinal plants. J. Ethnopharmacol. 2005; 97: 305-311.

[45] Abad MJ, Bermejo P, Villar A, Sanchez Palomino S, Carrasco L. Antiviral activity of medicinal plant extracts. Phytother. Res. 1997; 11: 198-202.

[46] Ruffa MJ, Wagner ML, Suriano M, Vicente C, Nadinic J, Pampuro S, Salomon H, Campos RH and Cavallaro L. Inhibitory effect of medicinal herbs against RNA and DNA viruses. Antiviral Chem. Chemother. 2004; 15: 153-159.

[47] Andrighetti-Frohner CR, Sincero TCM, da Silva AC, Savi LA, Gaido CM, Bettega JMR, Mancini M, de Almeida MTR, Barbosa RA, Farias MR, Barardi CRM and Simoes CMO. Antiviral evaluation of plants from Brazilian atlantic tropical forest. Fitoterapia. 2005; 76: 374-378.

[48] Calzada F, Yepez-Mulia L and Aguilar A. In vitro susceptibility of Entamoeba histolytica and Giardia lamblia to plants used in Mexican traditional medicine for the treatment of gastrointestinal disorders. J. Ethnopharmacol. 2006; 108: 367-370.

[49] Calzada F, Yepez-Mulia L and Tapia-Contreras A. Effect of Mexican medicinal plant used to treat trichomoniasis on Trichomonas vaginalis trophozoites. J. Ethnopharmacol. 2007; 113: 248-251.

[50] Vale TG, Matos FJA, Lima TCM and Viana GSB. Behavioral effects of essential oils from Lippia alba (Mill.) N.E. Brown chemotypes. J. Ethnopharmacol. 1999; 167: 127-133.

[51] Vale TG, Furtado EC, Santos JJG and Viana GSB. Central effects of citral, myrcene and limonene, constituents of essential oil chemotypes from Lippia alba (Mill.) N.E. Brown. Phytomed. 2002; 9: 709-714.

[52] Zetola M, Lima TCM, Sonaglio D, Gonzalez-Ortega G, Limberge RP, Petrovick PR and Bassani PR. CNS activities of liquid and spray-dried extracts from Lippia alba-Verbenaceae (Brazilian false melissa). J. Ethnopharmacol. 2002; 82: 207-215.

[53] Hennebelle T, Sahpaz S, Joseph H and Bailleul F. Phenolics and iridoids of Lippia alba. Natural Product Communications. 2006; 1: 727-730.

[54] Hennebelle T, Sahpaz S, Gressier B, Joseph H and Bailleul F. Antioxidant and neurosedative properties of polyphenols and 
iridoids from Lippia alba. Phytother. Res. 2007; 22: 256-258.

[55] Viana GSB, do Vale TG, Rao VSN and Matos FJA. Analgesic and antiinflammatory effects of two chemotypes of Lippia alba: a comparative study. Pharm. Biol. 1998; 36: 347-351.

[56] Guerrero MF, Puebla P, Martin ML, Arteag L and San Roman L. Assessment of the antihypertensive and vasodilator effects of ethanolic extracts of some Colombian medicinal plants. J. Ethnopharmacol. 2002; 80: 37-42.

[57] Gazola R, Machado D, Ruggiero C, Singi, G, Macedo Alexandre M. Lippia alba, Melissa officinalis and Cymbopogon citratus: effects of the aqueous extracts on the isolated hearts of rats. Pharm. Res. 2004; 50: 477-480.

[58] Puertas-Mejia M, Hillebrand S, Stashenko E and Winterhalter P. In vitro radical scavenging activity of essential oils from Columbian plants and fractions from oregano (Origanum vulgare L.) essential oil. Flavour Fragrance J. 2002; 17: 380-384.
[59] Stashenko EE, Jaramillo BE and Martinez JR. Comparison of different extraction methods for the analysis of volatile secondary metabolites of Lippia alba (Mill.) N.E. Brown, grown in Colombia, and evaluation of its in vitro antioxidant activity. J. Chromatography A. 2004; 1025: 93-103.

[60] Costa MCCD, Aguiar JS and do Nascimiento SC. Atividade citotoxica de extratos brutos de Lippia alba (Mill.) N.E. Brown (Verbenaceae). Acta Farmaceutica Bonaerense. 2004; 23: 349-352.

[61] Aiyelagabe. Antibacterial activity of Jatropha multifida roots. Fitoterapia. 2000; 72: 544-546.

[62] Nasar-Abbas SM and Halkman AK. Antimicrobial effect of water extract of sumac on the growth of some food born bacteria including pathogens. Int. J. Food Microbiol. 2004; 97: 63-69. 